\title{
Effect of Growth Temperature on the Lipids of Pseudomonas fluorescens
}

\author{
By C. O. GILL \\ Meat Industry Research Institute of New Zealand (Inc.), \\ P.O. Box 617, Hamilton, New Zealand
}

(Received 20 January 1975; revised I5 March 1975)

\begin{abstract}
SUMMARY
Pseudomonas fluorescens was grown in continuous culture with glucose or $\mathrm{NH}_{4}{ }^{+}$as the growth-limiting substrate. The total amount of lipid and the relative proportions of neutral lipid and phospholipid did not vary with the rate or temperature of growth. The amounts of the phospholipids, which were phosphatidyl glycerol, cardiolipin and phosphatidyl ethanolamine, altered with the type of growth limitation and with the temperature and rate of growth. A precise composition of phospholipid classes is not a requirement for growth at low temperature.

Fatty acid composition also varied with changes of these growth conditions at temperatures above $10{ }^{\circ} \mathrm{C}$, but at lower growth temperatures the degree of saturation of the lipids was strictly controlled, and was unaffected by changes in the growth rate or the nature of the growth-limiting substrate. The degree of saturation of the lipids was not critical at the higher growth temperatures, and the variation in the degree of saturation observed at these temperatures was due in part to a decreased ability of the organism to control the fatty acid composition of its lipids at temperatures above $10{ }^{\circ} \mathrm{C}$.
\end{abstract}

\section{INTRODUCTION}

The lipid composition of micro-organisms can show considerable variation with changes in the chemical and physical properties of the environment (Cronan \& Vagelos, 1972). Most work has been concerned with changes in the fatty acid composition. The increase of the unsaturated fraction of fatty acids with decrease of the growth temperature has received considerable attention (Farrell \& Rose, 1967; Schmidt-Lorenz, 1972); however, the proportions of the different lipid classes are also affected by the growth conditions. The relative proportions of bacterial phospholipid classes are affected by the growth rate (Cronan, 1968; Randle, Albro \& Dittmer, 1969) and by the pH and osmolarity of the growth medium (Houtsmuller \& Van Deenen, 1965; Munro \& Bell, 1973), but growth temperature has been reported to have no effect on the phospholipids of growing organisms (Haest, De Gier \& Van Deenen, 1969; Cullen, Phillips \& Shipley, I97I).

Variation in lipid composition with growth conditions has generally been studied using batch cultures in which several parameters may be changing simultaneously. At present, data on the effect of a single environmental factor on the overall lipid composition of a micro-organism are available only for the mesophile Saccharomyces cerevisiae (Hunter \& Rose, 1972), the lipids of which differ qualitatively from those present in bacteria.

Work with lipid auxotrophs has shown that the minimum temperature at which some membrane-associated processes can occur is dependent upon the lipid composition of the 
membrane (Esfahani et al. 1971; De Kruyff et al. 1973). The extent to which changes in the growth temperature affect the lipids of a cold-tolerant bacterium has therefore been studied in this context.

\section{METHODS}

Organism and growth. Pseudomonas fluorescens PDD35I3, a gift from Dr D. W. Dye of the Plant Diseases Division, Department of Scientific and Industrial Research, Auckland, New Zealand, was cultivated in a vortex-aerated fermenter of 21 working volume, similar in concept to that described by Marshall, Ratledge \& Norman (1973). Fresh medium was added and spent medium removed continuously by means of variable-speed, peristaltic pumps. The medium contained $(\mathrm{g} / \mathrm{l}): \mathrm{KH}_{2} \mathrm{PO}_{4}, 8 \cdot 0 ; \mathrm{K}_{2} \mathrm{HPO}_{4}, 7 \cdot 0$; nitrilotriacetic acid, O.I; $\left(\mathrm{NH}_{4}\right)_{2} \mathrm{SO}_{4}$ at 0.3 for nitrogen-limited growth and at $\mathrm{I} \cdot 0$ for glucose-limited growth. The $\mathrm{pH}$ was adjusted to 6.8 with $\mathrm{I} \mathrm{M}-\mathrm{NaOH}$; the steady-state $\mathrm{pH}$ was $6.6 \pm 0 . \mathrm{I}$. A trace-element solution was sterilized separately and added to give $\left(\mathrm{mg} / \mathrm{l}\right.$ growth medium): $\mathrm{FeSO}_{4}$.$\left(\mathrm{NH}_{4}\right)_{2} \mathrm{SO}_{4} \cdot 6 \mathrm{H}_{2} \mathrm{O}, 20 ; \mathrm{MgSO}_{4} \cdot 7 \mathrm{H}_{2} \mathrm{O}, 40 ; \mathrm{CaCl}_{2} \cdot 2 \mathrm{H}_{2} \mathrm{O}$, Io. Glucose solution was sterilized separately and added to give 4.0 and $\mathrm{I} \cdot 5 \mathrm{~g} / 1$ growth medium for nitrogen-limited and carbonlimited growth respectively. Sterilization was by autoclaving at $12 \mathrm{I}{ }^{\circ} \mathrm{C}$ for $30 \mathrm{~min}$.

Cultures were grown with continuous addition of medium for $40 \mathrm{~h}(200 \mathrm{~h}$ when specific growth rate $=0.0 \mathrm{I} \mathrm{h}^{-1}$ ) then $\mathrm{I} \cdot 5 \mathrm{l}$ of the culture was withdrawn and the cells pelleted by centrifugation at $10000 \mathrm{~g}$ for $20 \mathrm{~min}$. The bacteria were washed twice with water, lyophilized and then stored at $-5{ }^{\circ} \mathrm{C}$. Samples which had to be stored before lyophilization were held at $-18{ }^{\circ} \mathrm{C}$.

Extraction and analysis of lipids. Freeze-dried cells were twice extracted at room temperature with chloroform-methanol $(2: \mathrm{I}, \mathrm{v} / \mathrm{v})$ and the combined extracts evaporated to dryness in a rotary evaporator. The residue was redissolved in $10 \mathrm{ml}$ chloroform-methanol $(2: \mathrm{I}, \mathrm{v} / \mathrm{v})$ and washed with $2 \mathrm{ml} 0.88 \%(\mathrm{w} / \mathrm{v}) \mathrm{KCl}$, as described by Folch, Lees \& Sloane Stanley (I957). The chloroform layer was evaporated, the lipid weighed, and the neutral lipids and phospholipids were then quantitatively separated on columns of silicic acid by the procedure of Rouser, Kritchevsky \& Yamamoto (1967).

Neutral lipids were resolved on thin layers of activated silica-gel $G$ using hexane-diethyl ether $(\mathrm{I} 0: \mathrm{I}, \mathrm{v} / \mathrm{v})$ as solvent. Phospholipids were separated on thin layers of activated silicagel $\mathrm{H}$ using the following solvent systems: (I) chloroform-methanol-water $(65: 25: 4$, by vol.); (2) chloroform-methanol-7 $\mathrm{M}^{-\mathrm{NH}_{3}}$ (65:30:4, by vol.); (3) chloroform-methanolacetic acid-water ( $170: 24: 25: 4$, by vol.).

Solvent systems 2 and 3 were also used for two-dimensional chromatography (Nichols, 1964). The component lipids of the two fractions were identified by comparison of their behaviour in the solvent systems, indicated with that of standard lipids, and by their reactions with specific reagents (Skidmore \& Enterman, 1962; Dittmer \& Lester, 1964). Ubiquinone was identified by the spectrum of the oxidized and reduced forms when dissolved in ethanol (Lester et al. 1959).

Phospholipid classes were determined by phosphorus analysis of spots from thin-layer chromatograms developed with solvent $\mathrm{I}$, and visualized with iodine vapour (Rouser, Siakotos \& Fleicher, 1966).

The fatty acid composition of the total lipid was determined by gas chromatography (using a model 204-B Varian-Aerograph, Walnut Creek, California, U.S.A.) of methyl esters prepared by trans-esterification of lipid, using sodium methoxide (Marinetti, 1962). Methyl esters were separated on a $5 \mathrm{ft} \times \frac{1}{4}$ in glass column packed with $10 \%$ diethylene glycol succinate on $80 / 100$ Chromasorb W-AW at $175^{\circ} \mathrm{C}$, and the eluted compounds 
Table I. Effect of growth rate on the phospholipid composition of $P$. fluorescens grown in continuous culture at $30{ }^{\circ} \mathrm{C}$ with glucose or $\mathrm{NH}_{4}{ }^{+}$as the growth-limiting substrate

Phospholipids were separated and quantified as given in Methods. The results are the averages of three separate determinations in which individual quantities did not differ by more than $2 \%$ of the total phosphorus present.

\begin{tabular}{lcccc} 
Growth condition & $\begin{array}{c}\text { Specific } \\
\text { growth } \\
\text { rate }\left(\mathrm{h}^{-1}\right)\end{array}$ & $\begin{array}{c}\text { Phosphatidyl } \\
\text { glycerol }\end{array}$ & Cardiolipin & $\begin{array}{c}\text { Phosphatidyl } \\
\text { ethanolamine }\end{array}$ \\
\cline { 3 - 4 } Carbon limited & 0.35 & 17.4 & 14.1 & 68.5 \\
& 0.19 & 17.0 & 10.4 & 72.6 \\
& 0.10 & 16.1 & 9.3 & 74.6 \\
Nitrogen limited & 0.05 & 17.0 & 13.7 & 69.3 \\
& 0.35 & 12.1 & 24.0 & 63.9 \\
& 0.26 & 14.4 & 22.5 & 63.1 \\
& 0.11 & 18.9 & 11.7 & 70.8 \\
& 0.05 & 18.2 & 9.4 & 72.4
\end{tabular}

Table 2. Effect of growth temperature on the phospholipid composition of P. fluorescens grown in continuous culture at a specific growth rate of $0.05 \mathrm{~h}^{-1}$ with glucose or $\mathrm{NH}_{4}{ }^{+}$as the growthlimiting substrate

Lipid phosphorus was determined as in Methods.

\begin{tabular}{|c|c|c|c|c|}
\hline \multirow[b]{2}{*}{ Growth condition } & \multirow[b]{2}{*}{$\begin{array}{c}\text { Temperature } \\
\left({ }^{\circ} \mathrm{C}\right)\end{array}$} & \multicolumn{3}{|c|}{ Phospholipids ( $\%, w / w$, total lipid phosphorus) } \\
\hline & & $\begin{array}{l}\text { Phosphatidyl } \\
\text { glycerol }\end{array}$ & Cardiolipin & $\begin{array}{l}\text { Phosphatidyl } \\
\text { ethanolamine }\end{array}$ \\
\hline \multirow[t]{4}{*}{ Carbon limited } & 30 & $17 \cdot 0$ & $13 \cdot 7$ & $69 \cdot 3$ \\
\hline & 20 & $17 \cdot 3$ & $\mathrm{II} \cdot 3$ & $71 \cdot 4$ \\
\hline & 10 & 13.4 & $12 \cdot 0$ & $74 \cdot 6$ \\
\hline & 3 & $12 \cdot 7$ & $8 \cdot 9$ & $78 \cdot 4$ \\
\hline \multirow[t]{4}{*}{ Nitrogen limited } & 30 & $18 \cdot 2$ & $9 \cdot 4$ & $72 \cdot 4$ \\
\hline & 20 & I $8 \cdot 3$ & $8 \cdot I$ & $73 \cdot 6$ \\
\hline & 10 & $10 \cdot 0$ & $22 \cdot 7$ & $67 \cdot 3$ \\
\hline & 3 & $8 \cdot 7$ & $22 \cdot 6$ & $69 \cdot 7$ \\
\hline
\end{tabular}

identified by comparison of the retention times with those of standard compounds. Relative proportions of the fatty acids were calculated from the peak areas estimated from peak height $\times$ peak width at half peak height.

\section{RESULTS}

There was no significant variation of the quantity of extractable lipid or of the relative amounts of neutral lipids and phospholipids present in $P$. fluorescens. The average quantity of lipid obtained from 23 determinations was $86 \cdot 3 \pm 4 \cdot 2 \mathrm{mg} / \mathrm{g}$ freeze-dried bacteria. The total lipid contained $6 \cdot 2 \pm 0.6 \mathrm{mg}$ neutral lipid/I00 mg extracted lipid. The major components of all samples of neutral lipid were diglyceride, free fatty acid and ubiquinone. Traces of triglyceride were also present. No attempt was made to quantify the individual components of the neutral lipid. The polar lipid was resolved into three component phospholipids by thin-layer chromatography. The major phospholipid was phosphatidyl ethanolamine, with lesser amounts of phosphatidyl glycerol and cardiolipin. The relative amounts of these lipids varied with the growth conditions. 
Table 3. Effect of growth rate on the fatty acid composition of the total lipids of $P$. fluorescens grown in continuous culture at $30{ }^{\circ} \mathrm{C}$ with glucose or $\mathrm{NH}_{4}{ }^{+}$as the growth-limiting substrate

\begin{tabular}{|c|c|c|c|c|c|c|c|}
\hline \multirow[b]{2}{*}{ Growth condition } & \multirow{2}{*}{$\begin{array}{c}\text { Specific } \\
\text { growth } \\
\text { rate }\left(h^{-1}\right)\end{array}$} & \multicolumn{6}{|c|}{ Fatty acids $(\%, w / w$, total fatty acid $)$} \\
\hline & & I4:0 & I6:0 & I6:I & I7:0 cyc & $18: I$ & $\mathrm{U}$ \\
\hline \multirow[t]{4}{*}{ Carbon limited } & $0 \cdot 35$ & - & $28 \cdot 7$ & $43 \cdot 0$ & $5 \cdot 6$ & $22 \cdot 7$ & - \\
\hline & 0.19 & - & $33 \cdot 0$ & $42 \cdot 4$ & $8 \cdot 5$ & I6. I & - \\
\hline & $0 \cdot 10$ & 一 & $33 \cdot 7$ & $42 \cdot 7$ & I $1 \cdot 6$ & $12 \cdot 0$ & $\mathbf{T}$ \\
\hline & 0.05 & $\mathbf{T}$ & $34 \cdot 4$ & $30 \cdot 9$ & I $8 \cdot I$ & $16 \cdot 2$ & 0.4 \\
\hline \multirow[t]{4}{*}{ Nitrogen limited } & $0 \cdot 35$ & 0.6 & $30 \cdot 4$ & $39 \cdot 4$ & $4 \cdot 3$ & $25 \cdot 3$ & - \\
\hline & $0 \cdot 26$ & $2 \cdot 5$ & $33 \cdot 4$ & $32 \cdot 4$ & $9 \cdot 3$ & $22 \cdot 4$ & - \\
\hline & $0 \cdot I I$ & $I \cdot 3$ & $4 \mathrm{I} \cdot \mathrm{I}$ & $29 \cdot 4$ & $15 \cdot 8$ & I $2 \cdot 4$ & - \\
\hline & 0.05 & 0.8 & $45 \cdot 6$ & $20 \cdot 4$ & $20 \cdot 0$ & $13 \cdot 2$ & 一 \\
\hline
\end{tabular}

17:0 cyc, Methylene hexadecanoate; $U$, unidentified component with retention time indicating a 15:0 acid; $T$, trace.

Table 4. Effect of growth temperature on the fatty acid composition of P. fluorescens grown in continuous culture at a specific growth rate of $0.05 \mathrm{~h}^{-1}$ with glucose or $\mathrm{NH}_{4}{ }^{+}$as the growthlimiting substrate

\begin{tabular}{|c|c|c|c|c|c|c|c|}
\hline \multirow[b]{2}{*}{ Growth condition } & \multirow{2}{*}{$\begin{array}{l}\text { Temperature } \\
\left({ }^{\circ} \mathrm{C}\right)\end{array}$} & \multicolumn{6}{|c|}{ Fatty acids $(\%, w / w$, total fatty acid $)$} \\
\hline & & $14: 0$ & $16: 0$ & I6: I & 17:0 cyc & I $8: \mathrm{I}$ & \\
\hline \multirow[t]{4}{*}{ Carbon limited } & 30 & $\mathrm{~T}$ & $34 \cdot 4$ & $30 \cdot 9$ & I $8 \cdot I$ & $\mathrm{I} 6 \cdot 2$ & 0.4 \\
\hline & 20 & $\mathbf{T}$ & $29 \cdot 5$ & $46 \cdot 2$ & $5 \cdot 7$ & I $8 \cdot 6$ & $\mathbf{T}$ \\
\hline & Io & - & $20 \cdot 4$ & $52 \cdot 7$ & - & $26 \cdot 9$ & - \\
\hline & 3 & - & $2 \mathrm{I} \cdot 7$ & $52 \cdot 1$ & - & $26 \cdot 2$ & 一 \\
\hline \multirow[t]{4}{*}{ Nitrogen limited } & 30 & $0 \cdot 8$ & $45^{\cdot 6}$ & $20 \cdot 4$ & $20 \cdot 0$ & I3.2 & - \\
\hline & 20 & 0.3 & 30.4 & $42 \cdot 5$ & 8.0 & 18.8 & - \\
\hline & 10 & 0.3 & $22 \cdot 2$ & $48 \cdot 3$ & $2 \cdot 8$ & $26 \cdot 4$ & 一 \\
\hline & 3 & 0.4 & $2 I \cdot 9$ & $49 \cdot 3$ & $\mathrm{I} \cdot 8$ & $26 \cdot 6$ & $\cdots$ \\
\hline
\end{tabular}

For symbols, see Table 3 .

There was an initial decline in the amount of cardiolipin and to a lesser extent of phosphatidyl glycerol with increasing growth rate in carbon-limited cells, but the proportions of both components then increased so that there was a similar phospholipid composition at the two extreme growth rates examined. Under nitrogen limitation the proportion of cardiolipin increased with increasing growth rate, while the amounts of the other components decreased (Table I). Decreasing temperature increased the proportion of phosphatidyl ethanolamine whereas both the other fractions declined in carbon-limited cells, but under nitrogen limitation the major change with temperature was a marked increase in the amount of cardiolipin at 10 and $3{ }^{\circ} \mathrm{C}$ (Table 2 ).

The major fatty acids present in $P$. fluorescens were $\mathrm{C}_{16: 0}, \mathrm{C}_{16: 1}, \mathrm{C}_{17: 0}$ cyc and $\mathrm{C}_{18: 1}$ (Table 3). Traces of $\mathrm{C}_{18: 0}$ were detected in all samples; there was up to $3 \% \mathrm{C}_{14: 0}$ in nitrogen-limited but less than $\mathrm{I} \%$ in carbon-limited cells. The latter bacteria also contained traces of an unknown acid with the retention time of a $\mathrm{C}_{15}$ fatty acid. A similar component of Escherichia coli lipids has been observed (Cronan, I968). There was no indication of $\mathrm{C}_{\text {19:0 }}$ cyc formation; Knivett \& Cullen (1965), however, found that this fatty acid is not formed in growing $E$. coli. Cyclopropane fatty acid formation was stimulated by decreasing the growth rate (Table 3 ) and increasing the growth temperature (Table 4). Carbon-limitation had a minor effect in decreasing synthesis of $\mathrm{C}_{17: 0}$ cyc. The physical characteristics of 
Table 5. Effect of the growth rate on the fatty acids of $P$. fluorescens grown in continuous culture at $3{ }^{\circ} \mathrm{C}$ with $\mathrm{NH}_{4}{ }^{+}$as growth-limiting substrate

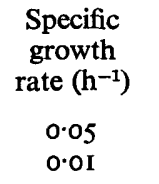

\begin{tabular}{|c|c|c|c|c|}
\hline \multicolumn{5}{|c|}{ Fatty acids $(\%, w / w$, total fatty acid) } \\
\hline 14:0 & $16: 0$ & $16: I$ & 17:0 cyc & 18:I \\
\hline 0.4 & $21 \cdot 9$ & $49 \cdot 3$ & $1 \cdot 8$ & $26 \cdot 6$ \\
\hline$T$ & $2 I \cdot I$ & $49 \cdot 6$ & $2 \cdot I$ & $27 \cdot 2$ \\
\hline
\end{tabular}

For symbols, see Table 3 .

phospholipids are not altered by substitution of cyclopropane acids for mono-unsaturated acids (Cullen et al, I97I).

Palmitic acid $\left(\mathrm{C}_{16: 0}\right)$ increased in concentration with decreasing growth rate (Table 3) and with increasing temperature (Table 4 ); nitrogen-limitation produced greater changes than carbon-limitation in both cases. There was little change in the amount of this acid on decreasing the growth temperature from 10 to $3{ }^{\circ} \mathrm{C}$ in bacteria grown under both types of nutrient limitation. Decrease of the growth rate also had no effect on the fatty acid composition of bacteria grown at low temperatures (Table 5).

The results show that for bacteria growing under nitrogen limitation, increasing the growth rate at a constant temperature had a similar effect on the lipids as decreasing the temperature at a constant growth rate. Presumably this occurred because in both cases the rate of catabolic activity relative to the rate of biosynthetic activity was being reduced, resulting in similar alterations of the intracellular concentrations of the metabolites which effect lipid synthesis.

\section{DISCUSSION}

Although there is considerable variation in the relative amounts of the three phospholipid classes with the temperature of growth, equally great variation can be observed at any constant temperature by alteration of the growth rate or of the growth-limiting substrate from the carbon to the nitrogen source. A precise composition of phospholipid classes, therefore, is not a requirement for growth at low temperatures.

It has been suggested that the membrane fatty acid composition of bacteria varies continuously over the growth temperature range and is controlled within narrow limits at any growth temperature (Sinensky, 197I; Cullen et al. 197I). However, the results reported here show that in $P$. fluorescens growing at near optimum growth temperatures, the degree of variation that occurred on varying the growth rate or changing the growth-limiting substrate from carbon to nitrogen was as great or greater than the variation due to alteration of the growth temperature alone. The degree of saturation did not vary continuously over the whole of the growth temperature range: a minimum degree of saturation of the lipids was attained at about $10{ }^{\circ} \mathrm{C}$ and further decrease of the growth temperature, or changes in the growth rate or the growth-limiting substrate, did not significantly alter the fatty acid composition. Pseudomonas fluorescens therefore controlled the fatty acid composition of its lipids over the lower third of its growth temperature range, to give a constant degree of saturation of the lipids. A precise degree of saturation of the lipids is apparently not required for normal growth at higher temperatures, and the increased saturation of the lipids at these growth temperatures seems to be due, at least in part, to the reduced ability of the controlling mechanism to compensate for the effects of alterations of the environment. 


\section{REFERENCES}

Cronan, J. E., Jun. (1968). Phospholipid alterations during growth of Escherichia coli. Journal of Bacteriology 95, 2054-206I.

Cronan, J. E., Jun. \& Vagelos, P. R. (1972). Metabolism and function of the membrane phospholipids of Escherichia coli. Biochimica et biophysica acta 265, 25-60.

Cúllen, J., Phillips, M. C. \& Shipley, G. G. (I97I). The effects of temperature on the composition and physical properties of the lipids of Pseudomonas fluorescens. Biochemical Journal 125, 733-742.

De Kruyff, B., Van Dijck, P. W. M., Goldbach, R. W., Demel, R. A. \& Van Deenen, L. L. M. (1973). Influence of fatty acid and sterol composition on the lipid phase transition and activity of membranebound enzymes in Acholeplasma laidlawii. Biochimica et biophysica acta 330, 269-282.

Dittmer, J. C. \& Lester, R. L. (I964). A simple method for the detection of phospholipids on thin layer chromatograms. Journal of Lipid Research 5, 126-I27.

Esfahani, M., Limbrick, A. R., Knutton, S., OKa, T. \& Wakil, S. J. (I97I). The molecular organization of lipids in the membrane of Escherichia coli: phase transition. Proceedings of the National Academy of Sciences of the United States of America 68, 3 I 80-3 184.

FArrell, J. \& Rose, A. H. (1967). Temperature effects on microorganisms. Annual Review of Microbiology 2I, IOI-I 20.

Folch, J., Lees, M. \& Sloane Stanley, G. H. (1957). A simple method for the isolation and purification of total lipids from animal tissues. Journal of Biological Chemistry 226, 497-509.

Haest, C. W. M., De Gier, J. \& Van Deenen, L. L. M. (1969). Changes in the chemical and the barrier properties of the membrane lipids of Escherichia coli by variation of the temperature of growth. Chemistry and Physics of Lipids 3, 4I3-4I7.

Houtsmuller, U. M. T. \& VAN DeEnen, L. L. M. (1965). On the amino acid esters of phosphatidyl glycerol from bacteria. Biochimica et biosphysica acta 106, 564-576.

Hunter, K. \& Rose, A. H. (1972). Lipid composition of Saccharomyces cerevisiae as influenced by growth temperature. Biochimica et biophysica acta 260, 639-653.

Knivett, V. A. \& Cullen, J. (1965). Some factors affecting cyclopropane acid formation in Escherichia coli. Biochemical Journal 96, 771-776.

Lester, R. L., Hatefi, Y., Widmer, C. \& Crane, F. L. (I959). Studies on the electron transport system. $\mathrm{XX}$. Chemical and physical properties of the coenzyme $\mathrm{Q}$ family of compounds. Biochimica et biophysica acta 33, I69-185.

MARINetTI, G. V. (1962). Chromatographic separation, identification and analysis of phosphatides. Journal of Lipid Research 3, I-20.

Marshall, B. J., Ratledge, C. \& Norman, E. (1973). Improved design for a simple and inexpensive multiplace laboratory fermenter. Laboratory Practice 22, 49 I-492.

MunRo, G. F. \& BeLl, C. A. (1973). Effects of external osmolarity on phospholipid metabolism in Escherichia coli B. Journal of Bacteriology 116, 257-262.

Nichols, B. W. (1964). In New Biochemical Separations, p. 32 I. Edited by A. T. James \& L. J. Morris. Princeton: van Nostrand.

Randle, C. L., Albro, P. W. \& Dittmer, J. C. (1969). The phosphoglyceride composition of Gramnegative bacteria and the changes in composition during growth. Biochimica et biophysica acta $\mathbf{1 8 7}$, 214-220.

Rouser, G., Kritchevsky, G. \& Yамамото, A. (1967). In Lipid Chromatographic Analysis, vol. I, pp. 99I62. Edited by G. V. Marinetti. New York: Dekker.

Rouser, G., Siakotos, A. N. \& Fleicher, S. (I966). Quantitative analysis of phospholipids by TLC and phosphorus analysis of spots. Lipids $\mathbf{I}, 85-86$.

SCHMidT-Lorenz, W. (1972). Physiologie des Wachstums von Mikroorganismen bei tiefen Temperaturen. Archiv für Lebensmittelhygiene 23, 268-272.

SINENSKY, M. (197I). Temperature control of phospholipid biosynthesis in Escherichia coli. Journal of Bacteriology ro6, 449-455.

Skidmore, W. D. \& Enterman, C. (1962). Two dimensional thin-layer chromatography of rat liver phosphatides. Journal of Lipid Research 3, 471-475. 